\title{
How to Promote the Korean Journal of Child Studies to an International Journal
}

\author{
Sun Huh \\ Department of Parasitology and Institute of Medical Education, \\ Hallym University College of Medicine, Chuncheon, Korea
}

\begin{abstract}
Objective: It aimed at proposing the Korean Journal of Child Studies' strategy to be promoted to international journal based on the style and format of scholarly journals and journal metrics.

Methods: The review of the journal in not only print version, but also an online version was done from the perspective of style and format. The total citation and impact factor were manually calculated from Web of Science Core Collection.

Results: More professional level manuscript editing is required for maintaining the consistency of the style and format. The verso page and back matters should be improved to international level. Journal homepage should be reconstructed by adopting digital standards for the journal, including journal article tag suite, CrossMark, FundRef, ORCID, and text and data mining. To become an international journal, transformation into English journal and deposition to PubMed Central is mandatory.

Conclusion: Since the editor's and society members' performance is top-notch, it will be possible to promote the journal up to international level soon. Society should guarantee the term of editor for enough time and support her with full cost and complete consent.
\end{abstract}

Keywords: Databases, Journal impact factor, Publications, PubMed, Societies

\section{Introduction}

Korean Journal of Child Studiesis an official journal of the Korean Association of Child Studies that launched in 1980. It published Volume 36 Number 6 in 2015. In this article, I would like to describe why this journal should be internationalized at first. After that I suggested a variety of strategies for the journal after reviewing style and format for not only print copies but also online issues and analyzing journal metrics. I hope this article to be helpful for the journal to be promoted to international one.

Corresponding Author: Sun Huh, Department of Parasitology and Institute of Medical Education, Hallym University College of Medicine, 1 Hallimdaehak-gil, Chuncheon 200-702, Korea.

Email: shuh@hallym.ac.kr

\section{Methods}

\section{Study design}

This article is a cross-sectional descriptive study based on the style and format of the journal and journal metrics.

\section{Materials}

The general concept of the international journal is described for

(CThe Korean Association of Child Studies

This is an Open Access article distributed under the terms of the

Creative Commons Attribution Non-Commercial License (http:// creativecommons.org/licenses/by-nc/4.0) which permits unrestricted noncommercial use, distribution, and reproduction in any medium, provided the original work is properly cited. 
common sense. I checked the style and format of the journal's recent issue based on the International Committee of Medical Journal Editors (ICMJE, http://icmje.org) and Scientific Style and Format $8^{\text {th }}$ format published by Council of Science Editors (http:// www.councilscienceeditors.org/). Journal metrics were calculated manually from Web of Science Core Collection database.

\section{Analysis method}

Descriptive analysis was done. Impact factor was calculated by checking the citation in Web of Science Core Collection. Total citation and countries of citing authors were counted. Results were presented in Table 1 and Figure 1.

\section{Ethical consideration}

This article is not intended to deal with the human or humanderived materials, so that it is not subject of institutional review board's activity.

\section{Results}

1. What is the international journal?

It is difficult to find the definition of international journal in the literature. It can be defined as follows: first, it can be read and used by international readers; second, international researchers can submit the manuscripts; third, journal editing should be international level according to its style and format; and, fourth, it should be indexed in international indexing databases. In Korea, an international journal by the National Research Foundation of Korea meant that it was indexed in SCIE, SSCI, A\&HCI, or SCOPUS. In addition to those databases, PsychoInfo, Medline, and PubMed Central/PubMed were other international databases in which this journal can be included.

2. Why should it be listed in the international indexing databases?

There are merits of recognition as the international journal of the
National Research Foundation of Korea (NRF) and the better rewards from the author's institution. If the journal is counted as an international one, there are advantages of authors to get the research fund from the NRF. In addition to those merits, the journal metrics, including journal network can be provided easily by those databases. Therefore, the position of the journal, journal access info, relationship with other journals, recent research trends, and trends of funding were easily caught up. Being indexed in those databases is essential for journal development (Huh, 2011).

\section{Review of style and format of recent issue}

\section{1) Verso page}

(1) Journal title: It can be more specifically presented as "Child development, parenting, and psychology. "This more specific title name may be more persuasive for researchers to read articles and submit the manuscripts.

(2) Aims and scope: Present aims and scope were simple as "submission is limited to manuscripts related with child studies." Furthermore, there should be more specific aims and scope that can be differentiated with other child studies journals in the world. Word count of the aims and scope should be at least 300. Scope is recommended to include child development, parenting, and psychology.

(3) Official abbreviated title: It is Korean J. Child Stud or Korean J Child Stud based on ISO journal title abbreviation (http://www. issn.org/services/online-services/access-to-the-ltwa/?letter=a).

(4) Editorial board members: At now all board members are Koreans. There should be invitation of board members from more than 30 countries. Association board members and editorial board members should do their best to recruit them. Pediatric psychiatrist, pediatric nurse, or pediatric psychologist also recommended to be invited to the editorial board so that the journal can be reviewed by a variety of professionals.

(5) Open access declaration: It was already free access journal so that it is easy to be transformed to open access journal by declaring the open access policy according to Creative Commons license (https://creativecommons.org/). Open access is better than free access for open access permits the use of data after clarifying the source of data. This journal is not a commercial one, but non- 
profit academic journal. Therefore, the publisher can declare the Creative Commons Attribution license (CC-BY) by adding the following sentence on the first page of each article: 'This is an openaccess article distributed under the terms of the Creative Commons Attribution License, which permits unrestricted use, distribution, and reproduction in any medium, provided the original work is properly cited.'

(6) Acid-free paper: If print version is published continuously, following sentence should be printed at the bottom of the verso page: 'It is printed on acid-free paper.'

\section{2) Article}

(1) Layout: Professional designer's layout format is required. After that, layout editor can work consistently with that format. Layout editor should understand what is necessary in journal editing. For example, in this journal, bibliographic information should be written in English. In English writing, there should be a space before the parenthesis. Type of font and font size, paragraph form, figures, and tables should be improved to international level. In the table, numerals should be aligned up to the right side. If there is a decimal place, decimal points should be a basis of alignment. In table legends, there should be no period; however, in the figure legends, there should be a period. In the table items, phrase or sentence should be aligned to the left side. Tables or figure should be prepared in full color for online version. For easy layout, professional layout program is recommended to be used. Excellent layout might be a professional layout editor's product. It can increase the readability of the article.

(2) Affiliation: In English affiliation, all co-author's department, institute, city, and country should be added.

(3) Length of main text: The limitation of the word count of main text up to 4,000 is recommended. The researcher is very busy so that short article is better for them. Number of references should be also limited up to 30 . Introduction part was too long due to the precise description of background. Therefore, word count of introduction part should be reduced to a maximum 500 . The aims of the study, specific objectives, hypothesis and most recent background were enough. In discussion and conclusion section, there should be a concise description of the results, the difference with other recent literature, limitation of the study, further recommended studies, and a short conclusion. To make article briefly, the easiest method is to think that if any sentences are essential to the conclusion process or not. Remove any text if an author convinces that it is no problem to reach the conclusion without this sentence. This method may be able to save only the backbone of the article's logical flow.

(4) Measuring tool in the methods section: If any measuring tools from journals published by commercial companies, author should get the permission from Copyright Clearance Center (http://www.copyright.com/). Sometimes, payment is required for use of data from those journals. In the articles of recent issue, it is not certain if authors got the permission by Copyright Clearance Center or not.

(5) Manuscript editing: Because there were some errors in the text, the professional manuscript editing is required. Also, under the help of manuscript editor, editor can maintain the style and format of the journal consistently.

(6) Reference style: Present APA (American Psychological Association) style is recommended to be changed to AMA (American Medical Association) style (http://www. amamanualofstyle.com/) so that reference errors can be reduced minimally. Example of AMA style reference is as follows:

“ 1. Huh S. How much is Journal of Educational Evaluation for Health Professions promoted based on journal metrics? J Educ Eval Health Prof 2015; 12:57."

The reason of better results by adopting AMA style was as follows: first, number of punctuation decreases dramatically; second, PubMed data can be moved without change; and third, readability is better because reference in the text is written as Arabic character in the square bracket ([ ]). If authors use reference management software, it is not difficult to adopt every reference style. Since not all researchers use that software, it is better to minimize the errors of references by adopting the AMA style.

(7) Publication date of references: Please cite only recently published articles less than ten years before, at author's best. If any articles were published more than ten years before, those were already included in the text book or discarded from the text book. It is not necessary to repeat the contents in the textbook. 


\section{3) Back matters}

(1) Instructions to authors: It should be described more precisely. A variety of publication types such as editorial, review, brief report, book review, obituary, letter to the editor, and continuing education may be helpful for the journal to be more interesting one. If there is article template, it will be easy for authors to write the manuscript.

(2) Research and publication ethics: It should be complemented according to ICMJE recommendation and Committee of Publication Ethics (COPE, http://publicationethics.org/) flow chart. Description of research and publication ethics is an essential item to be indexed to the above-mentioned databases. There should be permission from the Institutional Review Board of an author's institute with number if there were survey results. I recommend the association to register the journal to COPE or to participate as a member institute of COPE. It means that the journal keeps policy on the research and publication ethics according to COPE's guideline. Already 53 journals and one institute from Korea were registered to COPE as member journal or participating publisher up to February 2016.

\section{4) Online version}

(1) Online journalís digital standards: Journal article tag suite (JATS) XML, digital object identifier (DOI), CrossMark, FundRef, Text and data mining, open researchers and contributors ID (ORCID), Reference hyperlink, Cited-by, QR code, and audio-video file are examples of journal's digital standards. All of them should be adapted to journal publication to be competitive to other international journals. The online version has been read more frequently than the print version by researchers, according to the spread of the internet to the world. Most researchers meet the article in the online at first. They usually do not visit libraries to read the print version of journal at first.

(2) JAT S X ML: It is the standard XML for scholarly literature developed by the United States National Library of Medicine (NLM). NLM has made PMC XML since 2000. It was improved to JATS XML and became the National Information Standards Organization (NISO)'s and ISO's standard of journal XML in 2012. NISO is a United States-based organization, whereas ISO is the International Standard Organization (Huh, 2014). Full text JATS XML production of the Korean text article is possible since JATS XML accepts all character languages in the world. If JATS $\mathrm{XML}$ is produced, it can be deposited to ScienceCentral (http:// e-ScienceCentral.org) maintained by the Korean Federation of Science and Technology Societies. Journal deposited to ScienceCentral is searchable via Google Scholar and its full text is translated into 80 character languages in the world. Other merits of JATS XML are automatic conversion to other types of XMLs or user-interfaces: DOI/CrossRef XML, CrossMark XML, FundRef XML, ORCID XML, Directory of Open Access Journal (DOAJ) XML, PubReader format, and ePub 3.0 formats.

(3) DOI: It is the unique ID system of literature that provides continuous and perpetual direction of the full text of online articles, although there was a change of URL address of the journal. The DOI was already provided in this journal through Korea Science (http://koreascience.or.kr/) maintained by the Korea Institute of Science and Technology Information. Other merits of DOI system are reference hyperlink function which directs the full text of reference via DOI and cited-by function which makes it possible to know who cited that article.

(4) PubReader: It is the user-interface format to be visible in the online with consistent format and font size regardless of types of browsing machines such as laptop, tablet, smart phone, television, or smart watch. Automatic conversion to PubReader format from JATS XML is possible.

(5) Pub 3.0: It is the international standard of digital book. Similar to PubReader, content can read from any browsing machines.

(6) CrossMark: It is the system of informing recent version of article provided by CrossRef because there may be errata, corrigendum, or retraction after publication (Lammey, 2014).

(7) FundRef: It is the ID of funding agencies provided by CrossRef. Through FundRef, it is easy to trace articles supported by the specific funding agency. Funding agencies are searchable from http://e-sciencecentral.org/funder/.

(8) Text and data mining: It is the full text access system for researchers provided by CrossRef. If publishers participate in this system, full text from those publishers can be accessed as free although there may be some limitations. Therefore, it made easy researchers to do meta-analysis (Lammey, 2015). I recommend the association to participate in this system from: http://www.crossref. 
org/tdm/contact_form.html.

(9) ORCID (http://orcid.org): It is the unique ID of researchers and contributors. It is easy to find the author's biography and research works if author opens the data to public. It is recommended to request authors to add their ORCIDs. Especially it is useful for journals from Korea, since there are frequent appearances of different peopleof the same name. It is also useful to recruit the reviewers. Of course, there was already a researcher ID system not only in Korea, but also Researcher ID and SCOPUS Author ID in the world. However, ORCID is the general standard of author ID at present.

(10) QR code: It is the unique code to be possible to provide the information about specific objects by constructingthe bar code into two dimensions. It can read by scanner or digital camera. Recently, if $\mathrm{QR}$ code was scanned with smart phone, the URL address of the object is directed to at the same time. Therefore, it is recommended to adopt a QR code of journal or each article (Chang, 2014).

(11) Audio-video file: Providing audio or video files is a new trend of online journal. Full text or summary can be provided. Owing to the increased use of smart phone, listening and watching video become more convenient (Huh, 2013).

(12) Manuscript management system: Present system is only for Korean authors; therefore, the system in English should be constructed to recruit the manuscript from all over the world.

\section{Journal metrics}

Up to February 18, 2016, eight articles of the journal were cited from Web of Science Core Collection (Table 1). Sixteen articles have cited those eight articles. Frequency of citation according to year was presented in Figure 1.

Out of 17 citing articles, countries of authors and frequencies are as follows: Korea, 16; USA, 6; and Australia, 1.

Impact factor of year 2015

It can be calculated as below:

Number of citable articles of the journal in 2013: 56

Number of citable articles of the journal in 2014: 60

Total: 116
Table 1

Cited Articles of the Korean Journal of Child Studies in Web of Science Core Collection [cited 2016 Feb 18]

\begin{tabular}{lccrc}
\hline Cited author & Year & Volume & Page & $\begin{array}{c}\text { Citing } \\
\text { articles }\end{array}$ \\
\hline Chun, HY & 2003 & 24 & 151 & 1 \\
Chung, MJ & 1993 & 14 & 5 & 1 \\
Jae, KS & 1984 & 5 & 53 & 1 \\
Jang, Mikyung & 2005 & 26 & 47 & 1 \\
Kim, MJ & 2001 & 22 & 149 & 4 \\
Moon, Dae Geun & 2013 & 34 & 93 & 1 \\
Shin, SJ & 1998 & 19 & 27 & 7 \\
Sohn, HH & 2003 & 24 & 123 & 1 \\
\hline
\end{tabular}

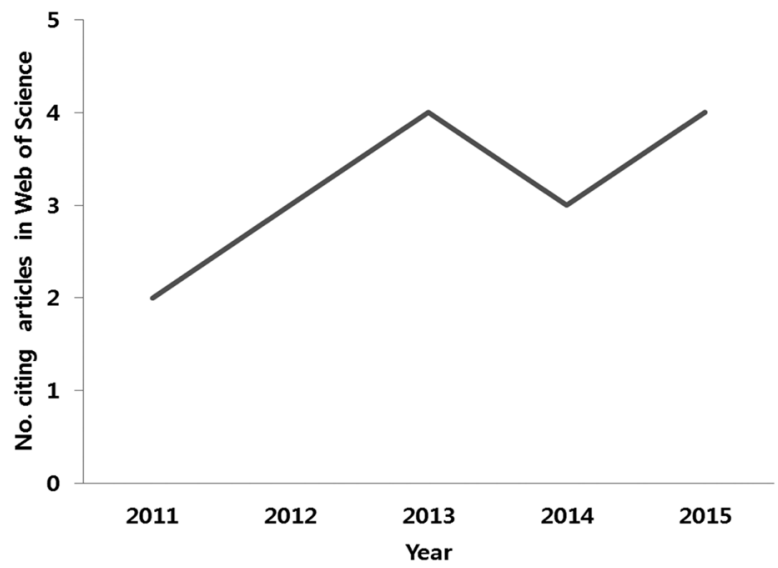

Figure 1. Number of citing articles in Web of Science Core Collection to the Korean Journal of Child Studies according to year.

Number of citations to the journal articles published in 2013 and 2014 from Web of Science Core Collection (SCIE, SSCI, and A\&HCI) articles published in 2015: 1.

2015 impact factor $=1 /(56+60)=1 / 116=0.009$

\section{Development strategy}

\section{1) Why is the impact factor of the journal not so high?}

Why is the journal not exposed to world researchers in the field of child studies? It is not due to low quality of articles, but lack of platform such as PubMed or PsychoInfo to be exposed to the international researchers. To overcome this situation, the journal 
should be indexed in PubMed or PsychoInfo.

\section{2) Is it eligible to be indexed in PubMed?}

It may be eligible because the Journal's scope included child development, parenting and psychology. Development and psychology is the scope of consideration by NLM that has maintained PubMed. For example, Child Development published by the University of Chicago Press in cooperation with the Society for Research in Child Development has been included in PubMed. Journal of Experimental Child Psychology, published by Academic Press has been also indexed in PubMed.

\section{3) How to be indexed in PubMed?}

There are two ways: One is applying to be Medline journal; the other is to provide the full text JATS XML (formerly PMC XML) after conversion of a journal language into English only to be listed in PMC. If the journal is indexed in PMC, PubMed XML file can be automatically dispatched to PubMed by PMC. To become Medline journal is very difficult due to strict criteria to be accepted. Only about $10 \%$ of applying journals can be accepted annually. It is the reason why more than 100 medical health journals from Korea have been indexed in PMC after changing text language only in English. Academic societies in Korea began to deposit PMC XML since 2008. PMC journal number from Korea reached at 117 on February 23, 2016. It is the third ranking according to country: England 501, USA 499, and India 111. If the journal is indexed in PubMed, there may be manuscript submission from all over the world. Also the journal can be a leading journal in Asia in the child studies field, since there is no PubMed journal from Asia in this field.

\section{4) How to recruit English manuscript?}

If any members wrote the manuscript in English, they will submit them to SSCI journal at first. It may be difficult to recruit English manuscript from the faculty members. The solution can be found from the PhD or Master's degree theses. Graduate students are succession generation. If we can train them to write a paper in English, and recruit their manuscript in the journal, the difficulty of submission number can be resolved. Workshop for writing English paper based on the thesis is recommended to be opened two or three times a year. Senior members of the Association can train them and professional writer who has experience of English translation also can be invited as facilitator. If they are well-trained, they can submit further research results in English to the journal without difficulties. Another tactic is to recruit the manuscript from all over the world by contacting acquaintances of editorial board members. Of course, it is difficult to recruit the manuscripts from international researchers; therefore, editorial board members should use their full network to ask submission. Also editorial board members should submit their manuscript to the journal at least once a year.

\section{5) Which databases or catalog should the journal apply to or register in after conversion to English journal?}

The editor should request the indexing to PMC, Medline, EBSCO, SCOPUS, and SSCI. EBSCO is one of the largest scholarly literature aggregates. If the journalis indexed in EBSCO, it is searchable from many libraries in the world. Registration to DOAJ is required if there is a declaration of open access policy. Thomson Reuters treats only DOAJ registered journals as open access. Before registering to DOAJ, registration to Sherpa/Romeo (http://www. sherpa.ac.uk/) is required, which discloses the policy on the deposit to institutional repository. The publisher can permit authors to deposit their manuscript before or after publication. Registration to NLM Catalog (http://www.ncbi.nlm.nih.gov/nlmcatalog/) is an urgent one to do right now. The Korean language journal also can be registered. To be registered to NLM Catalog, dispatch the print version to following address:

Serial Records Section, National Library of Medicine 8600 Rockville Pike, Bethesda, MD 20894, USA

Continuous delivery of the journal can be traced from NLM Catalog and NLM Holding Locator Plus.

\section{6) How long should editor work?}

The most important person in journal publishing is an editor. Therefore, it is recommended to guarantee editor's term at least five years up to ten years if possible. Furthermore, the full support by 
association is mandatory so that editors can work without burnout for a long time because all editors in Korea are working not as a full-time job but as voluntary work. The consistency of editing can be realized by the long-term appointment of an editor.

\section{7) How to increase impact factor?}

The solution is to be indexed in PMC. If Korean journal was transformed into English journal and was indexed in PMC, the impact factor and total citation may increase dramatically since the low citation is not originated from low quality articles but from lack of platform (Jeong \& Huh, 2014).

\section{Discussion and Conclusion}

Since the research competency of the Association members is excellent, above mentioned goals can be achieved by investing to journal editing and publishing. When leaders of the Association once decided the vision and goals of the journal, their driving force should be concentrated to realize those visions. During reform and changing process, leaders may confront the obstacles in or out of the organization. It should be overcome by frequent communication and training. If the journal is not internationalized, the submission to the journal may diminish year by year because member's research competency will become upgraded rapidly so that they would like to submit their research results only to international journals.

Journal publishing is another professional category. The brand value of specific journal cannot be achieved immediately. It is the reason why the United States and England have initiatives in journal publishing, where famous commercial publishing companies and academic societies have published thousands journals. To be competitive to those international journals, there is no way but publishing in English. The reason of low citation is originated from the language hurdle. Therefore, conversion to English journal will be a starting point to be international journal and it can be leading journal in Asia.

Journal publishing is a cooperative work with manuscript editor, English proofreader, layout editor, and information technology engineers besides of editors' and members' devotion. Without their professional help, journal cannot be published in an international level. Editors also should catch up the trends of journal publishing and editing by participating in the editors'workshop or seminar. If association guarantees the long-term editor's position and supports editor with full cost and consent, there will be no difficulty in reaching the goals of the journal in the near future.

\section{Acknowledgments}

This work was supported by the Hallym University Research Fund (HRF-G-2015-4).

\section{Conflict of Interest}

No potential conflict of interest relevant to this article was reported.

\section{References}

Chang, J. H. (2014). An introduction to using QR codes in scholarly journals. Science Editing, 1(2), 113-117.

H uh, S. (2011). W hy should Neurointervention be indexed in international databases? N eurointervention, $6(2), 49-50$.

$\mathrm{H}$ uh, S. (2013). Revision of the instructions to authors to require a structured abstract,digital object identifier of each reference, and authorís voice recording may increase journal access. J ournal of Educational Evaluation for $\mathrm{H}$ ealth P rofessions, 10, 3.

H uh, S. (2014). J ournal Article Tag Suite 1.0: N ational Information Standards Organization standard of journal extensible markup language. Science Editing, 1(2), 99-104.

J eong, G. H., \& H uh, S. (2014). Increase in frequency of citation by SCIE journals of non-M edline journals after listing in an open access full-text database. Science E diting, 1(1), 24-26.

Lammey, R. (2014). H ow to apply CrossM ark and FundRef via CrossRef extensible markup language. Science E diting, 1(2), 84-90.

Lammey, R. (2015). CrossRef text and data mining services. Science Editing, 2(1), 22-27.

\section{ORCID}

Sun Huh http://orcid.org/0000-0002-8559-8640 
甲 한글 요약본

\section{아동학회지를 어떻게 국제화시킬 것인가?}

허선

한림대학교 의과대학 기생충학교실 및 의학교육연구소

국제 학술지란 전 세계 독자가 읽고, 해당 분야 연구자들이 투 고할 수 있으며, 국제 기준의 편집 양식에 따라 출판하여 국 제 색인 데이터베이스에 등재된 학술지를 말한다. 우리나라 에서는 SCI(E), SSCI, A\&HCI, SCOPUS, PsychoInfo, Medline, PubMed 등의 데이터베이스가 잘 알려져 있다. 여기에 등재되 면 학자들 간의 네트워크, 학술지 이용 정도, 최근 연구 동향, 연구비 지원 등 서지계량정보를 쉽게 파악할 수 있기 때문에 학술지와 개인의 연구 역량 발전에 도움이 된다. 아동학회지 를 살펴본 결과 국제화를 위하여 개선하여야 점을 제시하면 다음과 같다.

\section{아동학회지의 형식과 양식에 대한 분석}

\section{판권란 부분}

- 학술지명: 학술지의 주제가 명확하게 드러나도록 기술해야 한다. Child development, parenting, and psychology와 같이 좀 더 구체적인게 좋다.

- 학술지의 목적과 성격: 아동학회지가 다른 국내 및 국제 학 술지와 어떤 차별을 지을 수 있는 지를 충분히 기술할 수 있 어야 한다.

- 공식 영문 약어명: Korean J Child Stud (ISO 약어)를 사용해 야 한다.

- 편집위원: 가능하다면 30 개국 이상에서 다양한 분야의 연구 자들이 참여해야 한다.

- Open access 선언: 현재 아동학회지는 무료 접근이 가능하므 로 이에 해당한다.

- 중성지 선언: 인쇄본 발행하는 경우 반드시 중성지임을 밝히 는 것이 필요하다.

본문

- 레이아웃: 국제 수준으로 제작하여야 한다. 최근에는 온라인 판을 더 많이 읽으므로 온라인은 칼라로 인쇄본은 흑백으로
제작하면 된다. 또한 레이아웃에 $\operatorname{InDesign(R)ㄱㅘ~ㄱㅏㅌㅇㅣ~ㄱㅜㄱㅈㅔㅈㅓㄱ~}$ 으로 널리 사용하는 도구를 활용하면 XML 작업도 훨씬 수 월하다.

- 저자 소속: 교신저자 뿐 아니라 모든 저자들의 소속 학과, 부 서, 기관명, 도시명, 국가명을 모두 표기하는게 낫다.

- 원고 길이: 짧은 원고가 더 좋다. 참고문헌 수를 제한하고 서 론의 중복을 줄이면 가능하다. 서론은 구체적인 목표와 가설 을 중심으로 기술하는 것이 필요하다. 방법과 결과는 지금 처럼 자세히 기술하면 된다. 고찰 및 결론에서는 결과를 간 단히 요약하면서 다른 연구와의 차별점, 제한점과 이후 연구 방향을 기술하면 충분하다.

- 측정 도구: 외국 상업출판사가 발행한 학술지에 실린 도구를 사용할 때는 반드시 Copyright Clearance Center에 도구 사용 에 대한 허락을 받아야 한다.

- 원고 편집: 가능하다면 원고편집 전문가에게 의뢰하거나 더 욱 철저하게 할 필요가 있다.

- 참고문헌 양식: AMA 양식으로 변경하면 연구자가 조금 더 편하다. AMA 양식은 구두점이 대폭 줄어서 오류를 최소화 할 수 있고 PubMed에서 쉽게 참고문헌으로 가져 올 수 있다 는 장점이 있다.

- 참고문헌 발행연도: 최근 10 년 이내 자료만 인용하도록 하고 이전 것 중 반드시 인용이 필요한 도구 등은 편집인과 상의 하도록 한다. 이미 10 년 지난 것은 교과서에 실리거나 없어 진 것들이므로 그 내용을 논문에 다시 기술할 필요는 없다.

\section{학술지 뒷면 투고규정 부분}

- 투고 규정: 조금 더 자세히 기술할 필요가 있다. 다양한 출판 유형을 다루어 조금 더 흥미로운 학술지로 키워나갈 수 있을 것이다.

- 연구출판윤리 기술: 국제 색인 데이터베이스 등재 심사에서 필수 사항이며 최근 더 집중하여 다루므로 국제 수준으로 다 듬을 필요가 있다. 특히, 기관생명윤리위원회의 승인 번호를 제시하도록 해야 한다. 학회 차원에서 $\mathrm{COPE}$ 에 회원 가입하 는 것도 방법이다.

\section{온라인 판}

- 온라인 학술지 전자 표준: JATS, XML, DOI, CrossMark, FundRef, Text and data mining, ORCID, Referece hyperlink, Cited-by, $\mathrm{QR}$ code, audio-video file 등 다양한 정보기술 도입 
하여 국제 수준에 손색없이 선보여야 한다. 독자들은 온라인 판을 훨씬 많이 보고 처음부터 인쇄본을 읽지 않는다.

- JATS XML: 이를 적용하여 ScienceCentral 등에 기탁하면 Google Scholar에서 쉽게 찾을 수 있고 국문을 80종의 언어로 번역하는 기능이 있어 외국인이 아동학회지 전문을 어느 정 도 이해할 수 있다. DOI는 논문의 고유번호로 웹에서 언제 든지 원문을 찾을 수 있는 기능이다.

- Reference hyperlink: 참고문헌에서 바로 해당 학술지 원문으 로 갈 수 있어야 한다.

- Cited-by: CrossRef를 통해 논문을 어느 학술지에서 인용하였 는지 확인할 수 있다.

- PubReader: 기기가 바뀌어도 웹에서 학술지를 일정한 폰트 크기로 쉽게 볼 수 있다.

- ePub 3.0: 전자책 국제 표준으로 어느 기기에서나 쉽게 읽을 수 있다.

- CrossMark: 논문의 최신성 여부를 알려주는 시스템으로 오류 나 철회를 알 수 있다.

- FundRef: 연구비 지원기관의 고유 번호이다.

- Text and data mining: 여러 출판사의 원문에 쉽게 접근할 수 있어 메타 분석에 활용.

- ORCID: 연구자의 고유 식별번호로 동명이인이 많은 우리나 라에서 매우 유용하다.

- QR code: 바코드를 인식하여 스마트폰에서 논문을 찾을 수 있다.

- Audio-video file: 최근에는 논문을 전부 비디오 파일로 제작하 는 경우도 있다.

- 투고관리시스템 정비: 국제적으로 투고 받으려면 아동학회 지도 국제 수준으로 시스템을 새로 구축해야 한다.

\section{아동학회지의 계량서지학적 분석}

현재 Web of Science Core Collection에서 인용된 아동학회지 논 문은 8편이며 이 8편을 인용한 논문은 모두 16 편이다. 인용한 논문은 한국계 연구자 또는 한국인과 공저자로 발행하여 순수 하게 외국인 저자 논문에서 인용한 예는 찾기 어렵다. 한국어 를 해독하지 못하는 외국인이 인용하기를 기대하기는 어렵다. 아동학회지의 2015 년도 영향력 지표는 다음과 같이 계산된 다.

2013년도 논문 수 + 2014년도 논문 수 $=56+60=116$ 이 논문 중 2015년에 Web of Science에서 인용한 회수 $=1$
2015년 아동학회지 영향력지표= $1 /(56+60)=1 / 116=0.009$

지금은 0.009 라는 수치가 낮아 보이지만 국문 학술지로서 이 렇게 인용 받는 일이 쉽지 않으므로 대단한 역량이다. 국내에 서 영향력 지표가 0 인 학술지가 상당히 많으므로 아동학회지 는 국제 학술지로서의 가능성을 확인할 수 있다. 앞으로 영문 으로 발행하여 PubMed Central에 등재되면 영향력 지표가 지 금보다 100 배 상승한다.

$$
\text { 국제 학술지로의 발전 전략 }
$$

아동학회지는 우수한 내용을 많이 게재하는데 인용 횟수는 왜 적을까? 그 이유는 학술지 수준이 낮아서 그런 것이 아니라 국제적인 플랫폼에 등재되지 못해서이다. 아동학은 발달, 양 육, 심리를 다루는 학술지 이므로 PubMed 등재가 가능하다. PubMed 등재에는 두 가지 방법이 있는 데, 하나는 Medline 선 정 심사를 통과하는 것이고, 다른 방법은 영문으로 발행하고 JATS XML를 제작하여 등재시키는 것이다. JATS XML 심사를 받기 위한 최소 논문 수는 25편이다. 국제 수준으로 제작하는 여러 회사의 도움을 받아서 학회지를 영문으로 발행한다면 기 술적인 어려움은 없다. 등재되면 전 세계 연구자가 논문을 투 고할 수 있고 아시아의 리더 학술지로 발전할 수 있다.

\section{초기에 어떻게 영문 논문을 수집할까?}

연구 후속세대인 석박사 대학원생을 대상으로 '학위 논문을 학술지에 투고하기'라는 주제의 워크숍을 여는 것이 최선이 다. 학술지 논문 작성은 학회 중견 회원이나 편집위원이 다루 고 번역 훈련은 번역 전문가를 초빙하여 방법을 익히면 충분 하다. 그 외 외국 학자에게 종설 원고를 받도록 해야 한다.

영문 전환 후 등재 신청하거나 등록할 데이터베이스

PMC, Medline, EBSCO, SCOPUS, SSCI에 등재 신청하여야 한 다. $\mathrm{EBSCO}$ 에 등재되면 전 세계 도서관에서 검색이 가능하다. Open access 선언을 하면 DDOAJ에 등록해야 한다.

\section{PubMed Central 등재 이후 변화}

회원들이 기뻐한다. 저자는 자신의 연구를 전 세계 연구자가 활용할 수 있고 아동 발달과 양육에 도움을 줄 수 있다는 점에 
서 기쁘다. 또한 전 세계에서 논문을 투고 한다. 이렇게 되면 편집인이 매우 바쁠 것이다. 학회 차원에서 인적, 물적 지원을 아끼지 말고 편집인 어깨위에 과중한 짐이 얹히지 않도록 하 여야 한다.

\section{편집인 임기}

학술지의 출판 및 발전 과정에서 편집인이 차지하는 비중은 $99 \%$ 라고 할 수 있다. 그러므로 편집인 임기를 보장하면서 학 술지의 일관성을 유지하여야 한다. 한편 인력과 경비를 충분 히 지원하여서 편집인이 지치거나 힘들지 않아야 한다. 그렇 지 않으면 오래 맡을 수가 없다.

\section{영향력 지표를 상승시키는 방안}

학술지가 SSCI에 등재될 때 평가에서 가장 마지막 과정에 다 루는 항목이 인용도이다. 전 세계 저자가 아동학회지를 인용 할 수 있어야 한다. 그러므로 영문 전환과 우수 논문 수집이 필 수이다. 영문 전환하여 $\mathrm{PMC}$ 에 등재시키지 못하면 영향력 지 표의 상승을 기대하기 어렵다.

\section{고찰 및 결론}

아동학회는 인적 자원이 우수하고 학회에서 관련 경비를 집중 투자하므로 빠른 시일 안에 국제 학술지로 발전할 것이다. 이 런 과정에서 학술지를 어떤 방향으로 발전시킬지 리더십이 중 요하다. 아동학회는 특히 아시아지역에서 국제 경쟁력을 갖추 는 데 유리하다. 나아가 전 세계에서 리더십을 발휘하는데 어 려움이 없을 것이다. 지금까지 아동학회지가 덜 알려진 것은 영문이 아니라는 장벽 때문이므로 영문 전환이 필요하다. 국 제학술지 발간은 편집인과 학회 회원의 힘만으로 할 수 있는 것이 아니라 원고편집인, 영문교열인, 레이아웃 편집인, 정보 기술 전문가 등 다양한 직종의 전문가와 함께 협력하여야 한 다.

Received February 23, 2016

Accepted February 27, 2016

저자 소개: 허선

\section{학력}

1982 서울의대 졸업

1990 서울대 박사 (기생충학 전공)

\section{경력}

1988-현 한림의대 기생충학교실 교수

1996-2011 대한의학학술지편집인협의회 정보관리위원회 위원장

2005-현 Journal of Educational Evaluation for Health Professions 편집인

2011-현 한국과학학술지편집인협의회 교육연수 및 기획운영위원장

2014-현 Council of Asian Science Editors, Chair of Education and Training Committee

2015-현 Learned Publishing, Associate Editor

\section{연구분야}

기생충 게놈, 의학교육에서 문항반응이론 적용과 컴퓨터바탕검사 시행, 학술지 국제화 자문 